dr. Timo

Toivianinen

Finska zveza za

izobraževanje

odraslih in

univerza

$\checkmark$ Helsinkih

\title{
SODOBNI RAZVOJ KAKOVOSTI V IZOBRAŽEVANJU ODRASLIH NA FINSKEM
}

\section{Javni interesi in zasebne pobude}

\begin{abstract}
$\mathbf{S}$
redi 80. let so si na Finskem začeli odločno prizadevati za spremembe $\mathrm{v}$ javni upravi. $\mathrm{S}$ tem je prišlo do premika od staromodnega modela upravljanja, temelječega na postavljanju norm, k novemu modelu upravljanja, zasnovanemu na informacijah. Različne veje javne uprave so se odpovedale inšpekcijam in drugim vrstam nadzornih ukrepov. Po drugi strani pa so vsi zainteresirani za izobraževanje, na primer financerji, organizatorji, udeleženci in drugi, izražali nenehne potrebe po informacijah o izobraževanju, zato so evalvacija, nadzor in zagotavljanje kakovosti postali pomembnejši kot kadarkoli prej.
\end{abstract}

\section{ZAKAJ SE JE PROBLEMATIKA KAKOVOSTI IZOBRAŽEVANJA V 90. LETIH PRERINILA V OSPREDJE?}

Resnična sprememba upravne kulture ne bi bila možna brez prenove, ki je zadevala duha in vsebino celotnega zakonodajnega aparata za potrebe izobraževanja. Ta vsesplošna prenova se je začela 1. januarja 1999. Pred tem je bilo za urejanje izobraževanja potrebnih več kot petdeset različnih zakonov, po prenovi pa jih je ostalo le osem. Bistvena značilnost nove zakonodaje je, da posamezni zakon predpisuje javni upravi in izvajalcu izobraževanja obvezo, da izpeljeta evalvacijo izobraževanja. ${ }^{1}$
Industrijsko razvite in manj razvite države so se bile prisiljene spoprijeti s posledicami gospodarske recesije, ki se je začela sredi 80 . let. Te posledice so bile še posebej resne na Finskem. Eden od pokazateljev njihove resnosti je bilo to, da je sredi najhujšega obdobja stopnja nezaposlenosti presegala 20 odstotkov. V teh okolǐšcinah se nobena veja javne uprave ni mogla izogniti zmanjšanju svojih proračunskih sredstev, to pa je le še povečalo potrebo po ovrednotenju izobraževanja. Aktivnosti je bilo treba nadaljevati $z$ dano kvoto, še pogosteje pa so bila sredstva še nižja, kar je zelo povečalo zahtevo po drugačnem obravnavanju vprašanj kakovosti. ${ }^{2}$

Ena najpomembnejših posledic recesije je bila, da je izobraževanje odraslih postalo delno odvisno od trga. To je velikokrat pomenilo, da je bilo javnih sredstev, ki so prihajala iz enega vira, manj in da je javna podpora na splošno postala bolj decentralizirana ter jo je bilo treba iskati pri različnih virih. Ker je bil pogosto nižji tudi celotni znesek javne podpore, je bilo treba iskati sredstva tudi iz drugih virov. Ponavadi je to pomenilo tudi potrebo po zvišanju šolnin. Vprašanja kakovosti izobraževanja so torej vzbudila novo zanimanje, države, izvajalcev izobraževanja in udeležencev. ${ }^{3}$ 
Za Finsko so pozna 80. in vsa 90. leta pomenila obdobje pospešene internacionalizacije $\mathrm{v}$ izobraževanju. Tudi to je povečalo pozornost, namenjeno vprašanjem kakovosti v izobraževanju, saj so ta vprašanja poudarjale mnoge mednarodne organizacije, bila pa so tudi $\mathrm{v}$ središču znanstvenega raziskovanja. ${ }^{4}$ Razlogi za večjo mednarodno pozornost, namenjeno vprašanjem kakovosti, so bili deloma enaki kot na Finskem: spremembe v upravni ter izobraževalni kulturi in gospodarska recesija.

\section{ČEMU POTREBA PO EVALVACIJI?}

Sočasno z razvojem sistema zagotavljanja in ugotavljanja kakovosti so se uveljavili trije argumenti, ki utemeljujejo potrebo po uvajanju ugotavljanja kakovosti kot bistvenega sestavnega dela izobraževanja:

a) Zagotavljanje kakovosti in druge oblike evalvacije zagotavljajo informacije za odločanje. V tem pogledu je odločanje opredeljeno kot kompleksen proces, ki ne vključuje le ljudi, ki odločajo o javnih političnih usmeritvah, temveč tudi izvajalce izobraževanja, učitelje in udeležence.

b) Recesija, ki smo jo doživljali v zadnjem desetletju, je povečala pritisk na zmanjšanje javnih sredstev za potrebe izobraževanja. Evalvacija zagotavlja argumente za najustreznejšo razdelitev zmanjšanih sredstev. Čeprav se razpoložljiva sredstva ne bi zmanjševala, bi evalvacija zagotovila možnosti, potrebne za alokacijo javnih sredstev.

c) Odgovornost je - ne glede na vir sredstev zelo pomembna. Za doseganje smiselno zastavljene odgovornosti je potrebna evalvacija.

V nadaljevanju je na kratko predstavljenih nekaj strateških ciljev evalvacije, ki jih je priporočila OECD. 5

\section{MODEL UGOTAVLJANJA KAKOVOSTI IZOBRAŽEVALNIH UČINKOV}

$\mathrm{V}$ letu 1994 je finska nacionalna komisija za izobraževanje (National Board of Education - NBE) začela načrtno razvijati zdajšnjo obliko ugotavljanja kakovosti izobraževanja. Leta 1998 je ta institucija za pedagoški razvoj objavila rezultate štiriletnega dela v priročniku Model ugotavljanja kakovosti izobraževalnih učinkov (A Framework for Evaluating Educational Outcomes). ${ }^{6}$ Ključni pojem v tej publikaciji je izobraževalni učinek, ki ga lahko opredelimo s tremi kategorijami, to so:

- učinkovitost,

- uspešnost (v ožjem smislu) in

- gospodarnost.

Treba je omeniti, da je bila v prejšnjih evalvacijah izobraževalnih učinkov pozornost omejena le na učinkovitost. Ker sta zdaj v evalvaciji upoštevani tudi uspešnost in gospodarnost, je postopek težavnejši, vendar daje tudi koristnejše informacije. Oglejmo si kratke definicije ključnih pojmov izobraževalnih učinkov - učinkovitosti, uspešnosti ( $v$ ožjem smislu) in gospodarnosti -, kot so uporaIzobraževanje opre-
deljujejo, učinkovi-
tost, uspešnost in
gospodarnost bljeni v tem modelu:

a) Izobraževanje je uspešno $v$ širšem smislu (succesful), če so bili doseženi cilji, določeni na nacionalni in mednarodni ravni za vse vrste organizacij, izobraževalne institucije in posamezne učne aktivnosti.

b) Izobraževanje je učinkovito (efficient), če so delovanje, prilagodljivost in časovno usklajevanje izobraževalnega sistema, izobraževalne uprave in organiziranega izobraževanja čim ustreznejši in če je kakovost izobraževanja zadovoljiva.

c) Izobraževanje je v ožjem smislu uspešno (effective), če veščine in kvalifikacije, ki jih zagotavlja, količinsko in kakovostno pospešujejo intelektualno rast posameznika ter razvoj družbe, kulture in delovne sfere. 
d) Izobraževanje je gospodarno (economical), če so bila sredstva zanj optimalno razporejena glede na cilje izobraževanja in če so bili zneski primerni glede na količino zagotovljenih storitev, strukturo in organizacijo zagotavljanja storitev.

Poleg ugotavljanja uspešnosti izobraževalnih učinkov po omenjenih kategorijah so v modelu predvideni tudi drugi dejavniki. Za evalvacijo je namreč treba opredeliti tudi cilje, kazalce in merila, tako da ima model obliko prikazano $\mathrm{v}$ tabeli.

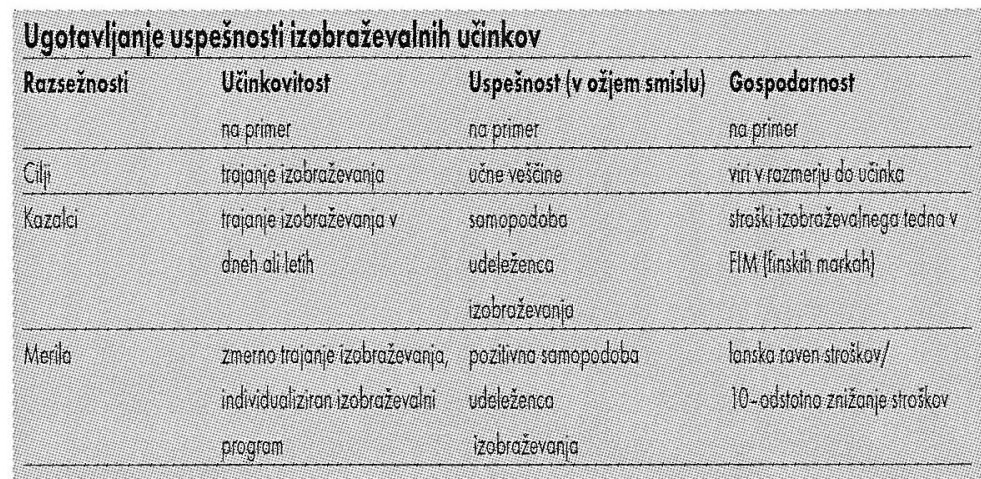

\begin{tabular}{|c|c|c|}
\hline \multicolumn{3}{|c|}{ Da bi bole razumeli razmeroma dvoumne kiuche poine, sl oglémo nekal primerov. } \\
\hline \multicolumn{3}{|c|}{ Uspesnostizobrazevalnh uénkov } \\
\hline Uinkoviosi & Uspesnosi yozten snislu & Cospodarnost \\
\hline \multirow{2}{*}{ Tobreierolpo ingudabo } & 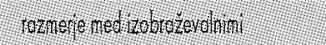 & 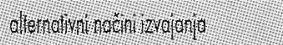 \\
\hline & 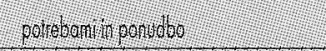 & 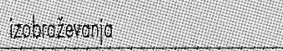 \\
\hline \multirow{5}{*}{ 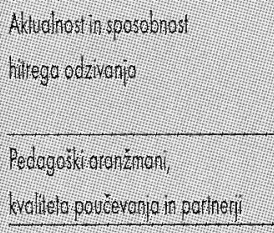 } & oosergenencing & 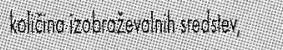 \\
\hline & & 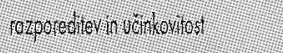 \\
\hline & & $770 \% 0$ porges \\
\hline & icrevigene & 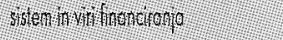 \\
\hline & & 2utraterent? \\
\hline \multicolumn{3}{|l|}{ Trogereledger } \\
\hline \multicolumn{3}{|l|}{ 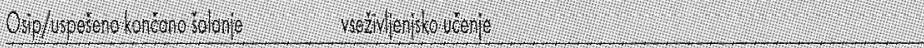 } \\
\hline \multicolumn{3}{|l|}{ 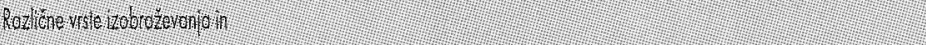 } \\
\hline \multicolumn{3}{|l|}{ 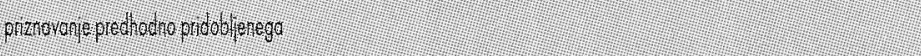 } \\
\hline \multicolumn{3}{|l|}{ zandiolervesch } \\
\hline \multicolumn{3}{|l|}{ (adif kol vi } \\
\hline \multicolumn{3}{|l|}{ Sitiventopere } \\
\hline \multicolumn{3}{|l|}{ 80utl 19 pegodoe } \\
\hline \multicolumn{3}{|l|}{ 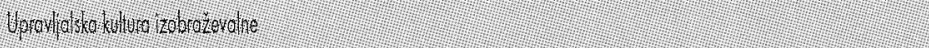 } \\
\hline organizacie & & \\
\hline
\end{tabular}

\section{IZVAJALCI EVALVACIJE IN NJIHOVI DOZDAJŠNJI REZULTATI}

Odgovorni za razvoj izobraževanja odraslih na Finskem se niso omejili zgolj na teorije, ki sem jih pravkar predstavil. Nasprotno, že več let se upravni organi in tudi posamezniki na odgovornih mestih v stroki ukvarjajo z različnimi načini ugotavljanja kakovosti ali pa so vsaj sprožili prizadevanja za razvoj sistematične evalvacije.

\section{a) Osrednji organ za ugotavljanje kakovo- sti: nacionalna komisija za izobraževanje (NBE)}

Naloga nacionalne komisije za izobraževanje je pedagoški razvoj izobraževalnega sektorja. Vprašanja kakovosti in druge teme, ki zadevajo evalvacijo, spadajo zato $\mathrm{v}$ pristojnost te komisije. V nadaljevanju bom na kratko predstavil tri evalvacije nacionalnega dometa, ki jih je komisija doslej izpeljala.

Prvo poročilo v tej seriji je bilo objavljeno leta 1996 z naslovom Organizacije za izobraževanje odraslih v letu $1995^{7}$. V poročilu je prikazano, kako je 270 finskih središč za izobraževanje odraslih preživelo zakonodajne spremembe in posledice gospodarske recesije, $s$ katerimi so se morali spoprijemati $\mathrm{v}$ zadnjih nekaj letih. Študija je bila izpeljana na vzorcu 33 središč za izobraževanje odraslih. Izbranih in analiziranih je bilo dvaintrideset kazalcev iz vsakega središča. Najpomembnejši sklepi:

- Organizacije za izobraževanje odraslih (Adult Education Centres - AEC) so ohranile vlogo najbolj razširjene oblike izobraževanja odraslih na Finskem. Njihovo omrežje, ki pokriva vse upravne enote, je mogoče razumeti kot temeljno storitev, ki je na voljo vsem državljanom. Ker pa je prišlo do porasta poklicnega izobraževanja odraslih, se je pomen središč (katerih glavna naloga je zagotavljanje splošnega, nepoklicnega izobraževanja) zmanjšal.

- Ekonomske in kurikularne razlike med or- 


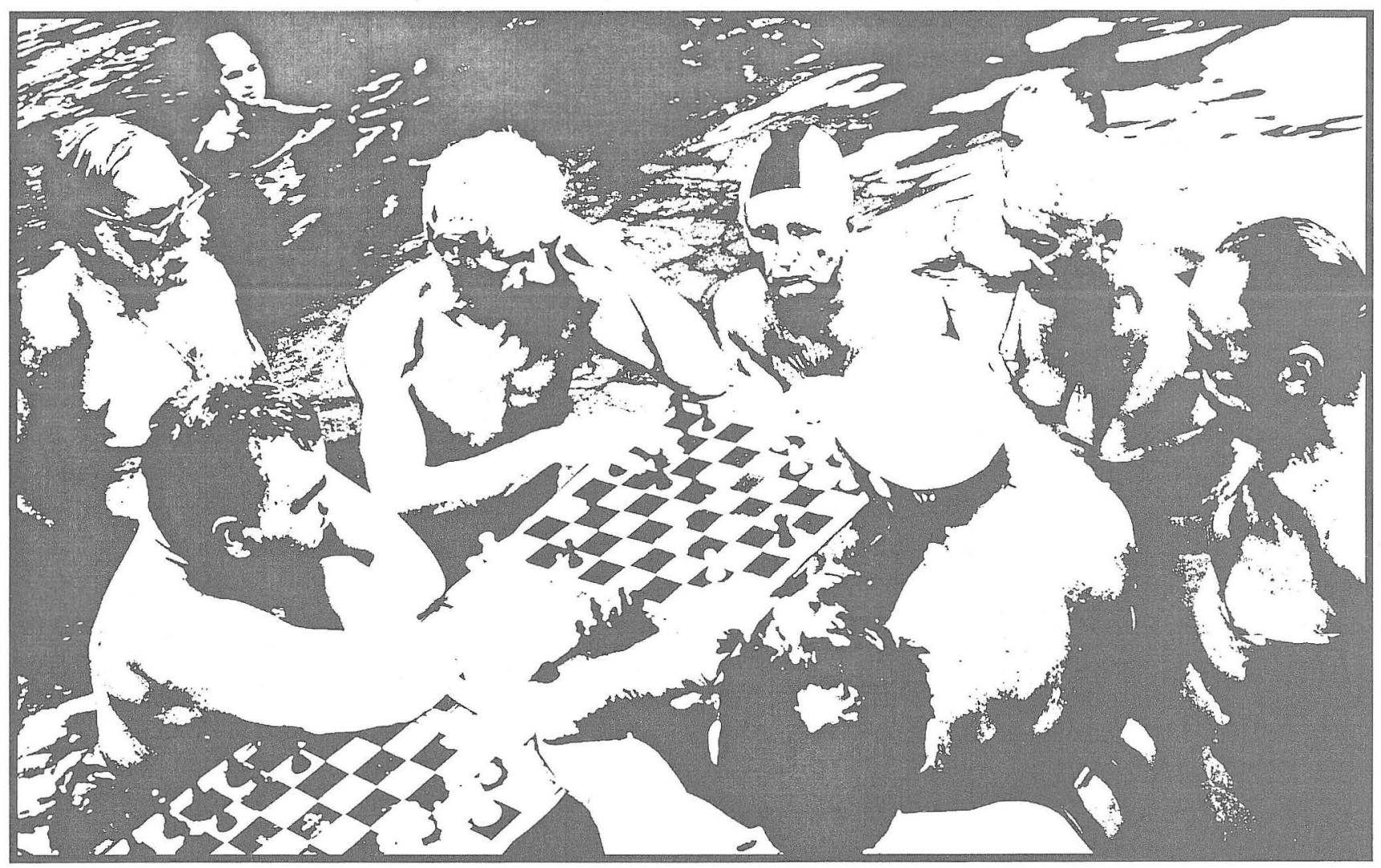

ganizacijami so se polarizirale. Za mnoge se z ekonomskega vidika ni nič spremenilo, nekatere pa so bile pred očitno gospodarsko in operativno krizo. Številne organizacije uživajo spoštovanje v svojih lokalnih skupnostih in jih pri vsakoletnem načrtovanju upoštevajo, še vedno pa je preveč takih, ki so zunaj glavnih tokov sedanjega časa in zdajšnjega razvoja.

- Večina izobraževalnih organizacij za odrasle je zmanjšanje vladne podpore nadomestila s povišanjem šolnin. V poročilu je čutiti skrb zaradi tega: če se bodo obračale zgolj na stranke, ki bodo sposobne plačati visoke pristojbine, bodo pripomogle $\mathrm{k}$ naraščanju neenakosti v izobraževanju, to pa je v protislovju z njihovim zgodovinskim poslanstvom.

Evalvacija, ki ne ovrednoti lastne kakovosti, je delno zavajajoča in je lahko celo nevarna. Pisci omenjenega poročila so se dobro zave- dali te nevarnosti. $V$ sklepnem delu avtorji skromno in $\mathrm{z}$ znatno mero intelektualne integritete menijo: $\gg V$ poročilu je mogoče najti poglavitna dejstva in eno od možnih interpretacij, toda hkrati s tem ko je naše pisanje napredovalo, se je zdela resnica vse bolj oddaljena.« (poudaril avtor članka)

Centri za študijske krožke so druga temeljna oblika izobraževanja $v$ splošnem izobraževanju odraslih na Finskem. V temeljno evalvacijsko raziskavo, ki je zajela 11 centrov v letu 1997, so bili vključeni tudi študijski krožki. Rezultati so bili objavljeni v poročilu z naslovom Evalvacija centrov za študijske krožke za leto $1997 .{ }^{8}$ Rezultati te raziskave so bili bistveno zanimivejši in bolj polemični kot ugotovitve razmeroma medlega poročila o organizacijah za izobraževanje odraslih. Razprave v finskih izobraževalnih krogih so med drugim spodbudili ti sklepi: 
- Vladna podpora centrom za študijske krožke se je zmanjšala, toda na presenečenje vseh, se je njihova dejavnost povečala. Evalvacija ni mogla ugotoviti negativnih učinkov zmanjšanja vladnih sredstev na kakovost njihovega dela. Zdi se, da je treba ponovno razmisliti o pomenu denarja $\mathrm{z}$ drugih vidikov.

- Zakonodajne in druge spremembe norm so zmanjšale vlogo birokracije, ki je posredovala med centri za študijske krožke in vlado. Razvila so se v centre virov za njihova organizacijska področja, novo operativno okolje pa jim je ponudilo boljše možnosti za predstavitev njihove izobraževalne ekspertize. Ker spadajo centri za študijske krožke v terciarni sektor, so s to spremem-

\section{Evalvacija je zelo učinkovita metoda za razdelitev jav- nih sredstev.} bo dosegli, da je postala avtonomija, ki so jo zahtevali v razmerju do vlade, jasneje opredeljena.

- Financiranje centrov za študijske krožke, odvisno od učinkovitosti njihovega delovanja, se je pokazalo kot slabo posnemanje prakse v šolskem sistemu.

- V poročilu je ostra kritika na račun nekaterih problemov, ki zadevajo centre za študijske krožke. Predvsem naj bi bili premalo na očeh javnosti. Avtorji tudi trdijo, da so organizacije - članice in druge stranke centrov večinoma soodgovorne za njihovo delovanje in da je precej manevrskega prostora za izboljšave. Najostrejša obtožba pa se nanaša na družbeno ter politično vlogo centrov za študijske krožke in izraža dvom o njihovi pomembnosti. Če pomislimo, da so prav študijski krožki tisti, ki se imajo za predstavnike finske civilne družbe, lahko razumemo, da so ti dvomi zelo resni in da so sklepi poročila spodbudili upravičeno kritiko.

Omenjeni poročili se nanašata na institucije, ki se ukvarjajo s splošnim izobraževanjem odraslih, ovrednoteno pa je bilo tudi poklicno izobraževanje odraslih.

Poročilo, ki je izšlo leta 1998 z naslovom Pedagoška evalvacija nadaljnjega poklicnega izobraževanja, ${ }^{9}$ pa je ponudilo osupljive ugotovitve:

- Za različna področja poklicnega izobraževanja so bili načrtovani novi izobraževalni programi, vendar se je izkazalo, da je njihova kakovost zelo različna in da so bili oblikovani pretogo. Posebej presenetljivo je, da izobraževalni programi niso usmerjali izpeljave izobraževanja, čeprav je to predpisano z zakonom. Prav tako naj bi imel vsak udeleženec individualni izobraževalni načrt, izkazalo pa se je, da je tako le v 30 odstotkih primerov.

- Sprejeti so bili udeleženci, ki niso izpolnjevali temeljnih pogojev za izobraževanje. Tudi pedagoške sposobnosti učiteljev bi bile lahko boljše. To je seveda pomenilo, da je bilo poučevanje na splošno slabo.

- Poklicno izobraževanje naj bi omogočalo pridobivanje veščin za delo. Vendar so se avtorji poročila čutili prisiljeni skleniti, da »je bilo težko najti tesno povezavo med delom ter načrtovanjem in izpeljavo tega izobraževanja .

Avtorji zaokrožujejo svoja temeljna spoznanja razmeroma kritično: »Na temelju evalvacijskih podatkov obstaja razlog za dvom o tem, ali se je nadaljnje poklicno izobraževanje za odrasle uresničevalo v skladu z določili statutov in $z$ razpoložljivimi viri.«

\section{b) Svet za izobraževanje odraslih (Adult Education Council - AEC)}

$\mathrm{Na}$ Finskem usmerja to področje svet za izobraževanje odraslih kot podporni organ ministrstva za izobraževanje. Svet se je dejavno vključeval tudi $\mathrm{v}$ problematiko ugotavljanja kakovosti.

Ta dokument je podrobneje predstavljen $\mathrm{v}$ prilogi na koncu prispevka. 
Decembra 1998 je svet objavil dokument Strategija ugotavljanja kakovosti v izobraŽevanju odraslih, ki obravnava pet tem:

- Kateri so razlogi za ugotavljanje kakovosti v izobraževanju odraslih?

- Kaj naj bo predmet ugotavljanja kakovosti v izobraževanju odraslih?

- Kako ugotavljati kakovost v izobraževanju odraslih?

- Kdo naj ugotavlja kakovost v izobraževanju odraslih?

- Priznanja za veliko kakovost v izobraževanju odraslih.

\section{c) Izvajalci}

\section{Organizacije za izobraževanje odraslih}

Kot sem opozoril na začetku, zdajšnja zakonodaja zahteva od izvajalcev, da ugotavljajo kakovost njihove dejavnosti. Vendar izvajalci niso čakali križem rok, da bi določila zakona začela veljati, temveč so začeli razvijati evalvacijsko prakso že pred mnogimi leti. Zato je lahko nacionalna komisija za izobraževanje v sodelovanju z organizacijami za izobraževanje odraslih že v letu 1997 pregledala vrsto samoevalvacijskih projektov, ki so že potekali. ${ }^{10}$ Njihova krovna organizacija je leta 1999 objavila načrt poizkusov in evalvacij Samoevalvacijski kriteriji delovanja organizacij za izobraževanje odraslih, 1999.11 Publikacija je rezultat pilotnega projekta Kakovost dejavnosti organizacij za izobraževanje odraslih, ki ga je financirala nacionalna komisija za izobraževanje.

Po letu 1997 so bili v približno 100 od 274 organizacij za izobraževanje odraslih izpeljani različni projekti za razvoj poučevanja. Zanimivo je, da sta evalvacija in problematika kakovosti spodbudili nastanek različnih pogledov na tem področju, ki se včasih med seboj zelo razlikujejo. Dokument, omenjen $\mathrm{v}$ opombi 11 , je prav tako le en pristop od mno-

gih. Gledano z vidika celote, je približno tretjina izobraževalnih organizacij dokaj učinkovito vključenih v projekte razvoja kakovosti, druga tretjina pa svoje sodelovanje šele načrtuje. Preostala tretjina za to še ni pokazala pretiranega navdušenja. Verjeten problem bo tudi, ta da bo odgovornost za izpeljavo evalvacije prepuščena majhni skupini navdušencev, večina osebja pa bo ostala pasivna. ${ }^{12}$

\section{Rezidenčne visoke ljudske šole}

Za rezidenčne visoke ljudske šole bo evalvacija na državni ravni izpeljana v letošnjem letu. Vendar ima ta sektor pionirsko vlogo na področju splošnega izobraževanja odraslih. Že leta 1993 je nacionalna komisija za izobraževanje objavila poročilo Samoevalvacija rezidenčnih visokih ljudskih šol. ${ }^{13}$ Poročilo je bilo zelo kakovostno, toda njegovi učinki so bili omejeni, saj je očitno nastalo prezgodaj.

Iz raziskave, ki zajema 93 rezidenčnih visokih ljudskih šol, izhaja, da jih je 33 odstotkov že izpeljalo projekte, ki zadevajo razvoj kakovosti, trenutno pa taki projekti potekajo v 40 odstotkih rezidenčnih visokih ljudskih šol. Le nekaj šol dela pr-

$\checkmark$ proces uvajanja kakovosti je treba vkljuciti vse zaposlene. ve korake na tem področju. V posameznih rezidenčnih visokih ljudskih šolah se je pokazalo, da je težko pritegniti celotno osebje in v njem vzbuditi pristno zanimanje za vprašanja kakovosti. Problem pa je tudi, da ljudje menijo, da za evalvacijo ni niti na voljo dovolj časa niti drugih virov. ${ }^{14}$

\section{Centri za študijske krožke}

Udeleženci študijskih krožkov večinoma prihajajo iz jasno opredeljenih ciljnih skupin. Da bi raziskali potrebe svojih strank in ocenili uspešnost svojega delovanja, so razvili različne sisteme samoevalvacije. Ker so študijski krožki izrazito svojevrstno področje splošnega izobraževanja, so se oblasti odloči- 
le, da se ne bodo pretirano ukvarjali z vprašanji kakovosti. Študijski krožki zato na tem področju napredujejo tako, kot ustreza njim in njihovim udeležencem. Zdi pa se, da se bliža čas, ko bodo potrebna skupna prizadevanja. Konec septembra 1999 so se njihovi predstavniki zbrali na skupni prireditvi. Razpravljali so o problematiki ugotavljanja kakovosti in se dogovorili o skupnih ukrepih, ki so jih študijski krožki sposobni izpeljati.

\section{Poklicno usposabljanje odraslih}

Leta 1994 je bil na Finskem vpeljan nov sistem kvalifikacij za poklicno izobraževanje odraslih, ki temeljijo na usposobljenosti. ${ }^{15} \mathrm{Ta}$ sistem obsega strokovne kvalifikacije za tri različne ravni usposobljenosti in teste za merjenje praktičnih ter teoretičnih strokovnih veščin. Te kvalifikacije urejata zakon (631/1998) in odlok (812/1998) o poklicnem izobraževanju odraslih. Če vas ta novi sistem zanima, aktualen je celo $\mathrm{z}$ vidika mednarodnih standardov, se lahko $\mathrm{z}$ njim seznanite $\mathrm{v}$ publikaciji nacionalne komisije za izobraževanje Kvalifikacije usposobljenosti, 1. januar 1999 (v angleščini). ${ }^{16}$ Hkrati s kvalitativno prenovo poklicnega izobraževanja odraslih izpeljuje nacionalna komisija za izobraževanje tudi evalvacijo tega področja. Ugotavljanje kakovosti in razvoj izobraževanja odraslih na Finskem napredujeta torej sočasno.

Mnogim institucijam poklicnega izobraževanja vlada pokriva le majhen delež njihovega proračuna. Njihova uspešnost torej temelji na visokih šolninah za kakovostne storitve in na dobrem slovesu, ki iz tega izhaja. Da bi si to zagotovile, so institucije poklicnega izobraževanja odraslih razvile zelo premišljene metode ugotavljanja kakovosti svojega dela. Uporabljajo jih za zbiranje informacij o izkušnjah udeležencev v izobraževanju.

Kot vemo, Finska predseduje Evropski uniji, zato je bila od 19. do 21. septembra $1999 \mathrm{v}$ Turkuju organizirana konferenca Vseživljenjsko učenje, splošno izobraževanje odraslih in civilna družba. Za ta seminar je ministrstvo za.izobraževanje pripravilo novo publikacijo, ki analizira finski sistem izobraževanja odraslih. ${ }^{17} \mathrm{~V}$ njej so predstavljeni najnovejši podatki in upoštevane vse spremembe, ki so se zgodile v zadnjem času.

\section{PRILOGA \\ Publikacija sveta za izobraževanje odraslih »STRATEGIJA UGOTAVLJANJA KAKOVOSTI VIZOBRA ŽEVANJU ODRASLIH«18}

\section{Razlogi za ugotavljanje kakovosti v izobraževanju odraslih}

Ugotavljanje kakovosti ima dva glavna namena:

- daje informacije za potrebe odločanja in

- izpolnjuje načelo odgovornosti.

Prvi namen ugotavljanja kakovosti, tj. za potrebe odločanja, temelji na tem, da so spoznanja, ki izhajajo iz ugotavljanja kakovosti, pomemben dejavnik na področju družbenega odločanja in upravljanja. V sistemu krmiljenja glede na ciljne rezultate ministrstvo za izobraževanje ter ministrstvo za delo v svojih re- sorjih postavljata cilje in spremljata njihovo uresničevanje. Politiki in vlada namreč potrebujejo informacije tudi o tem, kaj se dogaja na področju izobraževanja odraslih in kako so porabljena javna sredstva, namenjena temu področju. Organizacije - ustanoviteljice izvajalcev izobraževanja odraslih imajo podobne potrebe po informacijah.

Izobraževalne oblasti potrebujejo zanesljive informacije o finskem sistemu izobraževanja odraslih za mednarodne primerjave in mednarodno sodelovanje.

Organizacije za izobraževanje odraslih za potrebe upravljanja in za svoj razvoj potrebujejo informacije 
o lastni dejavnosti, dejavnostih drugih ter o celotnem sistemu. Evalvacijske podatke potrebujejo tudi, kadar želijo nagraditi svoje zaposlene ali uvesti tečaje in programe za pridobivanje priznanj. Odrasli udeleženci pa po drugi strani potrebujejo primerljive informacije o izobraževalni ponudbi in organiziranosti pouka, zato da lahko sprejemajo ustrezne odločitve. Delodajalci potrebujejo rezultate evalvacije za potrebe zaposlovanja in za razvojno usposabljanje svojih kadrov. Kakovost delovanja sistema izobraževanja odraslih prav tako zanima medije in najširšo javnost.

Odgovornost se nanaša na vprašanja legalnosti, donosnosti in stroškovne uspešnosti pri porabi javnih sredstev. Zakonodaja določa, kdo je odgovoren in katere so njegove obveznosti. Nova zakonodaja, ki zadeva poklicno usposabljanje odraslih, poklicno izobraževanje in splošno izobraževanje, je začela veljati 1. januarja 1999. Po teh zakonih so izvajalci usposabljanja (poklicno usposabljanje) in izobraževalne institucije (splošno izobraževanje odraslih) obvezani ugotavljati kakovost svojih storitev in njihove učinke, sodelovati pa morajo tudi pri evalvacijah, ki jih opravljajo zunanje institucije za ugotavljanje kakovosti. Po omenjenih zakonih je nacionalna komisija za izobraževanje odgovorna za razvoj ugotavljanja kakovosti in za vključevanje spoznanj zunanjih evalvacij v izobraževanje odraslih v skladu z usmeritvami, ki jih je izdalo pristojno ministrstvo. Ministrstvo lahko imenuje za izvedbo evalvacije poleg nacionalne komisije za izobraževanje tudi druge partnerje. Temeljna spoznanja vsake evalvacije morajo biti objavljena.

Politehniške šole morajo po zakonu o politehniških šolah zagotoviti kakovost svoje izobraževalne ponudbe in drugih dejavnosti, občasno pa se morajo udeleževati tudi zunanjih evalvacij.

Univerze morajo po zakonu o univerzitetnem izobraževanju ugotavljati kakovost svoje izobraževalne ponudbe, znanstvene ali umetniške dejavnosti in njihovih učinkov. Prav tako morajo sodelovati pri zunanjih evalvacijah. Ker omogočajo tudi nadaljnje strokovno izobraževanje in učenje na daljavo, se določila glede ugotavljanja kakovosti nanašajo tudi na te oblike.

Po veljanni zakonodaji mora svet za evalvacijo višjega izobraževanja pomagati institucijam višjega izobraževanja pri nalogah, ki zadevajo ugotavljanje $k a-$ kovosti: pregleduje prijave politehnikov za potrjevanje predznanja; organizira evalvacije, ki zadevajo dejavnosti in načrtovanje institucij višjega izobraževanja; daje pobude za ugotavljanje kakovosti; pospe-
Sosvet za izobraźevanje odraslih povzema temeljne razloge za ugotavljanje kakovosti vizobra zevanju odraslih s temi vprašanji:

- Ali je odrasti udeleženkifudeležencu omogočeno uresničevanje njenega/njegova śtudijskega projekta in ali so ji/nu zagotovljeni zadovoljiva kahovost storitev in primerno vodenje ter izobraževanje?

- Ali lahko izobraževanje odraslih zadovolji potrebe družbe in trga delovne sile, ki se stalno spreninjajo?

- Ali so javna sredstva, namenjena izobraževanju odrastih, uporabljena stroškovno učinkovito in v skladu z zakonodajo?

šuje raziskave na področju ugotavljanja kakovosti; skrbi za mednarodno sodelovanje na tem področju; ocenjuje specialistične programe, $k i$ jih institucije višjega izobraževanja ponujajo za potrebe ugotavljanja in potrjevanja predznanja.

Zakonodaja, ki zadeva usposabljanje za trg delovne sile, ne omenja ugotavljanja kakovosti kot takega, vendar pa se določilo, ki zadeva učinkovitost tega usposabljanja, nanaša na evalvacijske podatke in s tem na evalvacijo.

\section{Predmet ugotavljanja kakovosti v izobraževanju odraslih}

Uredbe in navodila oblasti zadevajo dva različna pristopa $k$ ugotavljanju kakovosti v izobraževanju odraslih: cilje ter pričakovanja, ki zadevajo izobraževanje odraslih, in dejavnike, določene posebej za evalvacijo. To so:

- ustreznost in učinkovitost sistema izobraževanja odraslih glede na spremembe na trgu delovne sile (do leta 2000);

- pismenost odraslih (OECD);

- sprotni postopki in običaji, ki zadevajo načela trajnostnega razvoja v vseh izobraževalnih ustanovah ( $z$ a leto 1999);

- nadaljnje strokovno izobraževanje učiteljev;

- ugotavljanje kakovosti vseh organizacij na področju izobraževanja odraslih (do konca leta 2000);

- ugotavljanje kakovosti usposabljanja, ki ga financirajo deželni vladni uradi;

- regionalno ugotavljanje kakovosti storitev izobraževanja odraslih, ki so na voljo državljanom.

Da se ne bi osredinili zgolj na sedanjo ponudbo izobraževanja odraslih, naj bi ugotavljanje kakovosti v izobraževanju odraslih vključevalo tudi tiste vidike, ki zadevajo izvajalčevo usmerjenost in predvidevanja za prihodnost, kot so akcijski načrti, sistemi povratnih informacij in upravljanje. 
Po mnenju sosveta bi bilo smiselno evalvacijske cilje umestiti v dve skupini: v prvi skupini so zadeve, ki zagotavljajo stalno spremljanje kakovostio njih naj bi se informacije zbirale v rednih intervalih. Gre za:

- izvajanje izobraževanja odraslih (uspešnost, stroškovna učinkovitost in vplivil:

- kakovost izobraževanja odraslih;

- zagotovitev načela enakosti v izobraževanju odraslih. regionalna distnbucija in dostopnost (na priner glede starosti, spola, drǔ̌beno-ekonomskega ozadja, zaposleninezaposleni).

Druga skupina vključuje cilje, katerih uresničevanje je treba ocenjevati, kadar je to potrebno. Po mnenju sosveta je treba nemudoma odgovoriti na ta vprašanja:

- kako sistem izobraževanja odraslih podpira vseživljenjsko učenje;

- kako sistem izobraževanja odraslih podpira različne vidike oselnnega razvoja, družbeno participaejo, pluralnost in pooblaš̌canje;

- kako so oblikovani individualni izobraževalni naěrti in kako delujejo;

- kakšni sta uspešnost in učinkovitost sistema poklicnih kvalifikacỉ in kako deluje;

- kako deluje sistem finančne podpore odraslin udeležencem;

- kako deluje zdajšnji sistem financiranja izobraževanja odraslih in kako izpolnjuje svoj namen:

- kakšna je ponudba izobraževanja za odrasle s posebnimi potrebami;

- kako delujejo podponne storitve v irobrazevanu odraslih.

- kako se izobraževanje odraslih odziva na potrebo po usposobljeni delovni sili?

\section{Način ugotavljanja kakovosti v izobraževanju odraslih}

Ugotavljanje kakovosti v izobraževanju odraslih je mogoče klasificirati glede na to, kdo ga izvaja:

- evalvacija znotraj določenega upravnega področja: nadrejena ustanova ocenjuje podrejeno ustanovo - izobraževalno institucijo ali organizacijo, za katero je odgovorna;

- zunanja evalvacija: upravno neodvisna agencija izpelje nepristransko evalvacijo;

- samoevalvacija: izvajalec ali druga ustanova, na primer izobraževalna institucija, ocenjuje lastno dejavnost.

Najboljše rezultate daje primerna kombinacija vseh treh oblik. Na informacijah, ki jih je mogoče zbrati s samoevalvacijo, še posebej temeljijo zunanje evalvacije.

Ugotavljanje kakovosti v izobraževanju odraslih pa lahko klasificiramo tudi glede na končni namen evalvacije:

- razvojno-usmerjena evalvacija: opisna analiza de- lovanja, kakovosti in stopnje doseganja ciljev izobraževanja odraslih; cilji so lahko povezani z družbenim in kulturnim razvojem, individualnimi aspiracijami po razvoju in s potrebami poslovnega sveta, industrije in trga delovne sile;

- evalvacija prenove: ocena uspešnosti prenove izobraževanja odraslih ali uspešnosti razvojnega projekta; razlog za tako evalvacijo je ponavadi politično-upravne narave.

Da bi bil zagotovljen dostop do izčrpnih, vsestranskih in zanesljivih informacij, je treba pri pripravi gradiva za ugotavljanje kakovosti v izobraževanju odraslih upoštevati različne uporabne metode. Viri za to so lahko: raziskave, mnenja strokovnjakov, kvantitativne in kvalitativne »monitoring « raziskave ali kombinacija omenjenih metod.

Glavni viri podatkov, potrebnih za ugotavljanje kakovosti, so statistika, vzorčenje in vnaprejšnje meritve. Vsi razvojni načrti in pilotni projekti morajo vedno vključevati ugotavljanje kakovosti.

Sosvet navaja nepogrešljiva merila dobre evalvacije:

1. evalvacijska spoznanja so zanesliva, informativna, aktualna in razvojno naravnana;

2. evalvacija ustreza razmeran, stroski so razumni;

3. evalvacijski postopki so v skladu z interesi vseh vključenili strank;

4. evalvacija je izpeljana podrobno in nataněno, njen namen je zagotoviti korektne, trajne in razumljive informacije:

5. evalvacijska spoznanja so objavljena in s tem dostopna vsem zainteresiranim.

Namen ugotavljanja kakovosti v izobraževanju odraslih mora biti nenehni razvoj. Pri vodenju in upravljanju morajo biti uporabljena spoznanja evalvacije. To spodbuja številne stranke, ki so vključene, da zavzamejo pozitiven odnos do evalvacije in da dejavno sodelujejo pri evalvacijskem procesu.

Evalvacija mora biti izčrpna, osrediniti se mora na razpoložljive vire in na druge možnosti ponudbe, procese, neposredne rezultate in dolgoročne učinke. Merila, uporabljena v evalvaciji, izhajajo iz postavljenih ciljev izobraževalnih storitev, dejavnosti in vrednot, na katerih temeljijo, ali pa iz standardov, ki so bili določeni posebej v ta namen.

Po mnenju sosveta kazalci učinkovitosti niso primerni za ugotavljanje kakovosti v izobraževanju odraslih 


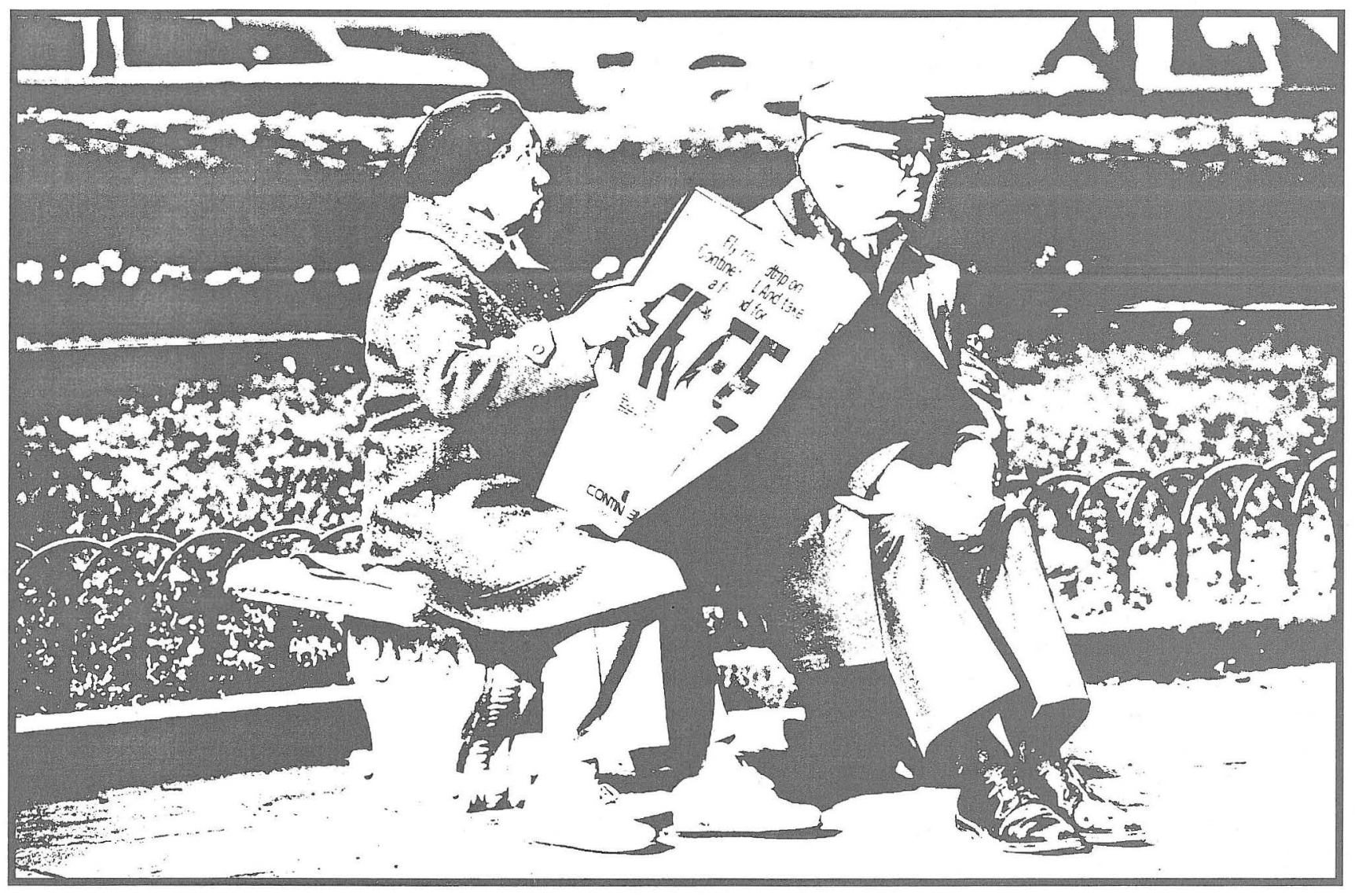

na Finskem, zato niso vključeni v strategijo. Sosvet pa vendarle poudarja, da je treba še naprej razvijati količinske in kakovostne kazalce za izobraževanje odraslih.

\section{Kdo naj ugotavlja kakovost v izobraževanju odraslih?}

Najpomembnejši partnerji pri ugotavljanju kakovosti v izobraževanju odraslih so:

- udeleženci izobraževanja,

- izobraževalne institucije,

- različne civilne skupine,

- delodajalci in

- javna uprava (državna/lokalna).

Nova izobraževalna zakonodaja zahteva, da lokalne oblasti in drugi, ki zagotavljajo izobraževanje in usposabljanje, ovrednotijo lastno izobraževalno ponudbo ter njeno učinkovitost in da sodelujejo $v$ zunanjih evalvacijah lastne dejavnosti. Poskrbeti morajo za to, da izobraževalne institucije in organizacije, ki jih upravljajo, izvajajo samoevalvacijo in objavljajo ugotovitve, prav tako pa morajo biti njihove dejavnosti predmet zunanjih evalvacij, ki jih izvajajo neodvisni ocenjevalci.

Zakon izobraževalni instituciji, ki se ukvarja s splošnim izobraževanjem odraslih, nalaga dolžnost, da ugotavlja kakovost svoje izobraževalne ponudbe in da se udeležuje zunanjih evalvacij. Te institucije morajo torej izpeljati samoevalvacije in objaviti njihove ugotovitve. Poleg tega morajo njihove storitve ovrednotiti neodvisni ocenjevalci.

Sosvet poudarja, da bi mu morale dajati izobraževalne institucije in organizacije za sistematično uporabo povrame informacije, $k i$ jih dobijo od udeležencev. Te institucije in organizacije morajo oblikovati učinkovit sistem zbiranja povratnih informacij, ki omogoča udeležencem, da ocenijo, koliko so jim celotna izobraževalna oskrba, poučevanje, vodenje, usmerjanje in lastno delo ponnagali doseči cilje, ki so si jih zastavili. Ta sistem je sestavni del institucionalne samoevalvacije, seveda pa je uporaben fudi za zunanje evalvacije. 
Uěinkovito in primeno oceno kakovosti zagotavlja le nepristransto ugotavljanje kakovosti v izobraževanju odrashih. Sosvet se v zvezi s tem strinja z mnenjen, izraženim v parlanentu: 'Ugotavljanje kakovosti mora organizirati nacionalna komisija za izobraťevanje, tako da bo neodvisno od drugih struktur; uspešnost evalvacijske strukture je treba ponowno preveriti ěez die leti.

Mediji, prostovoljske organizacije in posamezniki različno ocenjujejo kakovost v izobraževanju odraslih: $v$ televizijskih in radijskih oddajah, časopisnih člankih, javnih razpravah, pismih uredništvom ali s pozivi oblastem. Odgovorni za izobraževanje odraslih bi morali spremljati javno mnenje in ga upoštevati pri svojem razvojnem delu.

Socialni partnerji preučujejo potrebe po delovni sili in po razvojnem usposabljanju kadrov. Objavljajo kratkoročne napovedi o omenjenih potrebah in ocenjujejo uspešnost sistema izobraževanja odraslih pri zagotavljanju usposobljene delovne sile.

Interne evalvacije izobraževalnega sektorja izvajajo nacionalna komisija za izobraževanje in deželni vladni uradi. Ocenjujejo dejavnost in uspešnost institucij za izobraževanje odraslih glede na postavljene cilje, porabo javnih sredstev in obravnavajo vprašanja, povezana z zakonsko zaščito udeležencev. Po novi zakonodaji je za to pristojno predvsem ministrstvo za izobraževanje, ki določa razvojna načela za ugotavljanje kakovosti in zunanje evalvacije. Postopek evalvacije razvija nacionalna komisija in tudi izvaja zunanje evalvacije. Ministrstvo lahko evalvacijo zaupa tudi drugim partnerjem, ne samo nacionalni komisiji. Slednja je le eden od partnerjev, ki pomagajo uresničevati načela ministrstva.

Sosvet meni, da morajo oblasti ugotavljati kakovost izobraževanja in usposabljanja, ki ga financirajo. Za evalvacijo irobraževanja odrashih ni potreben specifičen organ, na primer svet za evalvacijo visjjega šolstva. Evalva. cijo lahko primerno izpelje pristojio ministrstvo in nacionalna komisija. Sosvet za izobraževanje odraslih, ki je neodvisen od upravmh ablasti, lahko deluje kot zunani organ, ki da mnenje, predlaga evalvacijske cilje in obravnava evalvacüske ugotovitve.

Svet za evalvacijo višjega izobraževanja ugotavlja kakovost dejavnosti institucij višjega izobraževanja, pregleduje prijave politehnikov za potrjevanje predznanja in ocenjuje specialistične programe, ki jih ponujajo institucije višjega izobraževanja.

Ministrstvo za delo ugotavlja kakovost usposabljanja odraslih v svojem sektorju. To vključuje usposabljanje za trg delovne sile in usposabljanje, ki ga financirajo središča za zaposlovanje in gospodarski razvoj. Čeprav zakonodaja ne obvezuje ministrstva za delo, da izvaja evalvacije, je ministrstvo samo ocenilo, da je primerno za izvajanje evalvacij za njihove dejavnosti. Večino usposabljanja za trg delovne sile izvajajo izobraževalne institucije, $k i$ so podrejene izobraževalnim oblastem. Sosvet ugotavlja, da morajo upravni organi za delo in za izobraževanje okrepiti medsebojno sodelovanje pri ugotavljanju kakovosti v izobraževanju odraslih.

Na zahtevo ministrstva za notranje zadeve ugotavljajo kakovost izobraževalnih storitev, ki so na voljo prebivalcem, vštevši izobraževanje odraslih, deželni vladni uradi. Gre za ocene z vidika posameznika, osredinjajo se na razpoložljivost in na kakovost storitev. Deželni vladni uradi ocenjujejo tudi tiste izobraževalne storitve, $k i$ jih financirajo.

Komisija Evropske unije zahteva, da je v vsakem programu Evropske unije poskrbljeno za ugotavljanje kakovosti. Za to je odgovorna nacionalna »monitoring skupina, posebej imenovana za ta namen.

\section{Priznanja za izjemno kakovost v izobraževanju odraslih}

$V$ skladu z razvojnim načrtom izobraževanja in univerzitetne ga raziskovanja naj bi bilo financiranje izobraževanja odraslih zastavljeno tako, da je - tam, kjer je potrebno - možno delno prilagajanje, odvisno od uspešnosti izvajalca. Tak sistem je težko vpeljati

Sosvet ugotavlja, da je eno od možnih meril za nagrajevanje lučnkovitega delovanja na področju izobraževianja odrastih izjemna kakovost. V ta namen lahko izobraževalne institucije in organiza cije predlagajo določeno izobraževalno storitev ali izdelek (doloćeno résitev v okvinu izobraževalne ponudbe, técaj, izobraževalni program, pod. pomo stonitev ipd.), za katero menijo, da zasližzi priznanje Čeprav je pojen izjemne kakovosti. izobraževanju odrastih zelo obsiren, je bistveno, da je predlagana resitev izraz poslanstva in strategije institucije ali organizacije. Predlagana storitev ali izdelek mora bith kenkrena in že uweljavljena, tako da je z njo mozho dokazati sposobnost institweje ali organizacije da uresnicuje svojo politiko un stmategijo. Sisten, ki nagrauje izjemmo kakovost, dopusica, da za priznanje kandidira celoten sistem izobraževanja odraslih. Možni sta ave enakovredni nagradi y, minmalnem znesku 300.000 FIM. Po mienju sosveta naj bi bilo na voljo dovoli sredstev tudi za to, da se zagotomi ugotanljanje kakovosti wet predlogov in da wi kandilati dobijo povratno infonnacijo. 
za financiranje institucij in organizacij izobraževanja odraslih, saj temelji to financiranje večinoma na enotnih stroških ali pa je odvisno od prihodkov od izobraževalnih storitev. Zato je le malo možnosti za povezovanje rezultatov izobraževalne evalvacije $s$ financiranjem izobraževalnih institucij in organizacij. Sosvet se zavzema za ukrepe, ki bi omogočili to povezovanje, s tem da se upošteva razvoj struktur, ki podpirajo in pospešujejo akcije, ki sledijo evalvacijskim ugotovitvam.

Institucije in organizacije izobraževanja odraslih je možno nagraditi s spodbudami. Tovrstna shema nagrajevanja se ujema s politiko ministrstva za izobraževanje, namenjeno nagrajevanju institucij višjega izobraževanja, skupaj z izobraževanjem odraslih, za kakovostne izobraževalne storitve.

$1 \check{C}$ e vas zanima finska zakonodaja, obiščite spletne strani (http://finlex.om.fi). Drugo gradivo, ki zadeva izobraževanje odraslih, lahko najdete na spletni strani ministrstva za izobraževanje ( $w w w . m i n e d u . f i)$.

2 Posledica recesije je bila, da je splošno izobraževanje odraslih na Finskem (tj. središča za izobraževanje odraslih, rezidenčne visoke ljudske šole in študijski krožki) v letih 1992-1995 izgubilo približno 26 odstotkov državne podpore.

3 Risto Rinne in Markku Vanttaja sta spremembe, ki so se v zadnjih dveh desetletjih zgodile v finskem izobraževanju odraslih, ovrednotila v študiji Politika izobraževanja odraslih na Finskem: spremembe in razhajanja, Helsinki, 1999, 154 strani. Študijo je naročil svet za izobraževanje odraslih, ki jo je med drugim želel uporabiti za ovrednotenje vladne politike izobraževanja.

${ }^{4}$ Glej na primer publikaciji OECD Izobraževanje na prvi pogled: analiza (Education at a Glance: Analysis) Pariz, 1996, in Kako izboljšati prakso ugotavljanja kakovosti: najboljši praktični napotki za evalvacijo (Improving Evaluation Practices: Best Practice Guidelines for Evaluation) in (njen) temeljni članek na internetu (http://www.oecd.org/puma/) ali Nabrusimo naša orodja: kako izboljšati ugotavljanje kakovosti v izobraževanju odraslih in v neformalnem izobraževanju (Sharpening our Tools: Improving Evaluation in Adult and Nonformal Education), zbral in uredil Peter A. Easton, objavil Unescov inštitut za izobraževanje v: UIE Studies 4, Hamburg, 1996.

${ }_{5}^{5}$ Glej publikacijo OECD »Improving Evaluation Practices«, omenjeno v opombi 4.

${ }^{6}$ Nova, revidirana izdaja knjige »A Framework for Evaluating Educational Outcomes in Finland« je prišla na trg oktobra 1999.

7 Poročilo, ki obsega 158 strani, je na voljo le v finskem jeziku.

\& Poročilo, ki obsega 134 strani, je na voljo le v finskem jeziku.
${ }^{9}$ Poročilo, ki obsega 167 strani, je na voljo le v finskem jeziku.

10 Rezultati so bili objavljeni v poročilu Anne Rosenius z. naslovom Samoevalvacijski projekti delovanja organizacij za izobraževanje odraslih v letu 1997, nacionalna komisija za izobraževanje, Helsinki, 1999, 51 strani.

"I Zveza organizacij za izobraževanje odraslih, Helsinki, 45 strani: študija Samoevalvacijski kriteriji za delovanje organizacij za izobraževanje odraslih, 1999, kot rezultat pilotnega projekta Kakovost dejavnosti organizacij za izobraževanje odraslih, Nacionalna komisija za izobraževanje.

${ }^{12}$ Memorandum, naslovljen na ministrstvo za izobraževanje dne 17. 8. 1999, avtorica Eeva-Inkeri Sirelius z, naslovom Razvijanje samoevalvacijskega sistema organizacij za izobraževanje odraslih.

13 Nacionalna komisija za izobraževanje. Samoevalvacija rezidenčnih visokih ljudskih šol: prvi del memoranduma delovne skupine, ki jo je imenovala nacionalna komisija za izobraževanje za potrebe ugotavljanja kakovosti delovanja rezidenčnih visokih ljudskih šol, Helsinki, 1993, 65 strani s prilogami.

${ }_{14}$ Memorandum, ki ga je Timo Tuomisto naslovil na Ministrstvo za izobraževanje dne 17. 8. 1999: Evalvacija izobraževanja v rezidenčnih visokih ljudskih šolah.

15 Kratek opis tega sistema je na voljo v publikaciji, izdani v angleškem jeziku Kvalifikacije. Informacija izpitnim komisijam in institucijam, ki organizirajo izpite. Nacionalna komisija za izobraževanje, Helsinki, 1994.

16179 strani (Competence-based Qualifications 1st January 1999).

17 Naslov publikacije je Izobraževanje na Finskem. Izobraževanje odraslih (Education in Finland Adult Education).

18 Helsinki, 1998 (ISBN 952-442-990-X). 